\title{
Space Planting, Competition, and Productivity of a Seven-Year-Old Clonal Teak Plantation in the East Java Monsoon Forest Area
}

\author{
Rika Bela Rahmawati ${ }^{1}$, Suryo Hardiwinoto ${ }^{1 *}$, Widiyatno ${ }^{1}$, Budiadi ${ }^{1}$, Yahya Amin ${ }^{2}$, Aulia Hasanusi ${ }^{2}$ \\ ${ }^{1}$ Department of Silviculture and Agroforestry, Faculty of Forestry, Universitas Gadjah Mada, \\ J1. Agro No. 1 Bulaksumur, Yogyakarta, Indonesia 55281 \\ ${ }^{2}$ Center for Forestry Research and Development Perhutani, Jl. Wonosari Tromol Pos 6 Cepu, \\ Central Java, Indonesia 58302
}

Received January 19, 2021/Accepted June 23, 2021

\begin{abstract}
Tree breeding of teak results in selected clones with high growth. Intensive silviculture is required to support a largescale clonal teak plantation. Appropriate spacing is one of the methods to increase forest plantation productivity. Research of teak clone spacing was conducted on a seven-year-old clonal teak plantation with randomized completely block design. The treatments tested in this study were four plant spacing distances, namely, $3 \mathrm{~m} \times 3 \mathrm{~m}, 6 \mathrm{~m}$ $\times 2 \mathrm{~m}, 8 \mathrm{~m} \times 2 \mathrm{~m}$, and $10 \mathrm{~m} \times 2 \mathrm{~m}$. Results show that spacing had significantly different effects on diameter, height, bole height, branch angle, crown area, crown projections, volume, and competition index. However, the height growth did not exhibit any significant differences. The $10 \mathrm{~m} \times 2 \mathrm{~m}$ spacing produced the best diameter growth, crown area, and competition index, but has a low volume per hectare and the lowest height of free branch and branch angle. Meanwhile, the $3 m \times 3 m$ spacing will increase bole height and stand volume per hectare. This result suggests that spacing could improve the growth of teak clone but must be followed by intensification of proper maintenance to reduce branch angle and increase bole height.
\end{abstract}

Keywords: teak clones, space planting, intensive silviculture, productivity

*Correspondence author,email:suryohw@ugm.ac.id, tel.+62-274-512102,fax.+62-274-550541

\section{Introduction}

Teak (Tectona grandis L.f.) is the most important hardwood species in the world (FAO, 2013) because of its strength, straightness, workability, resistance to many pests and diseases (Zanin, 2005), and durability and stability (Palanisamy et al., 2009). In the timber trade, teak is a highvalue product from an economic, environmental, and social perspective, and is a major component of the forest economy in many tropical countries (Wehr et al., 2016; Zhou et al., 2017). Globally, teak is the only hardwood resource planted on a large scale and has attracted large investments from the private sector in Africa, Asia, and Latin America (Kollert \& Cherubini, 2012).

The world's source of teak wood is $>29$ million ha of natural forests and 6.89 million ha plantations (Kollert \& Chaerubini, 2012). The global consumption of teak continues to increase, whereas the source of teak from natural forests decreases due to illegal logging and competition with other natural resources. Efforts to plant teak globally are needed. Teak forest plantations in the world cover between 4.35 to 6.89 million ha, of which more than $80 \%$ are grown in Asia, $10 \%$ in Africa, and 6\% in tropical America (Kollert \& Kleine, 2017). The largest teak forest in Indonesia is found on the island of Java, in which the teak forest area is 1,000,534 ha or $67 \%$ of Java's production forest (Perhutani, 2014). Teak plantations are declining due to forest degradation. In 2012, teak forests in Java covered an area of 1,750,860 ha (MoF, 2012), which means a decrease of 750,326 ha.
Teak breeding in Indonesia has been conducted since 1983-1997 with a collection of 680 plus trees from various locations in Indonesia, the final goal of which is to increase the productivity of teak plantations (Na'iem, 2000). Thus, a selected plus trees would be established for progeny and clonal tests to produce superior seeds and improve tree genetic traits related to growth, stem form, branching, and resistance to pests and diseases (Na'iem, 2000; Ling et al., 2009). Tree breeding of teak showed that two superior clones (numbers 97 and 110) were selected and planted in various places in Java in 2003 (Na'iem, 2012). The selected teak clones have a diameter of $>2-4 \mathrm{~cm}$ (Na'iem, 2000).

To support large-scale clonal teak plantation, plant spacing needs to be adjusted to enable the teak plants to grow optimally, produce quality wood products (Iddi et al., 1996), and achieve a large diameter (Zahabu et al., 2015). Some spacing distances used in teak plantation studies include $1.37 \mathrm{~m} \times 1.37 \mathrm{~m}, 1.98 \mathrm{~m} \times 1.98 \mathrm{~m}, 2.9 \mathrm{~m} \times 2.9 \mathrm{~m}($ OlaAdams, 1990); $1 \mathrm{~m} \times 1 \mathrm{~m}$ (Haninec et al., 2016); and $2 \mathrm{~m} \times 2$ $\mathrm{m}, 3 \mathrm{~m} \times 3 \mathrm{~m}$, and $4 \mathrm{~m} \times 4 \mathrm{~m}$ (Zahabu et al., 2015). However, the mean annual increment (MAI) of teak's diameter remained low, ranging from $1.1 \mathrm{~cm}$ year ${ }^{-1}$ to $1.8 \mathrm{~cm}_{\text {year }}{ }^{-1}$ ). In contrast, the selected superior teak clone has high and fast growth, thereby probably needing more space for growth and to produce high-quality wood. Moreover, the fast growth of teak clone could increase competition among individuals in the early years of their growth. A previous study showed that increasing the competition indices affected diameter and 
basal area growth (Contreras et al., 2011; Maleki et al., 2015). A study on the effect of spacing on clonal teak has never been conducted. On the other side, clonal teak had higher growth than unimproved teak (Naíem, 2000; Budiadi et al. 2017), thus the early growth evaluation should be conducted to maintain the optimum growth of clonal teak until the end of rotation. As a long rotation species, the initial spacing of teak would affect tree growth and ensure competition among individuals. Monitoring early growth of clonal teak at 7 years after planting in different spacing should be evaluated to provide an understanding of the spacing effect on growth. On the other side, different planting spacing would show the intensity of competition among individual trees (Harrington et al., 2009). Therefore, this study needs to be performed to broadly support large-scale clonal teak plantations.

\section{Methods}

Study site and research design The research was conducted on a seven-years-old clonal teak plantation located at KPH
Ngawi Perhutani, East Java, Indonesia, at latitude $\mathrm{S}^{\circ} 22^{\prime} 52.829^{\prime \prime}$ and longitude E111 $18^{\prime} 17.466^{\prime \prime}$ and is a lowland monsoon forest. The average temperature varies between $32-37^{\circ} \mathrm{C}$ with an average humidity of $40-50 \%$. The dominant soil texture is clay soil with medium solum. The climate of the region is the D type based on the SchmidtFerguson climate classification, with a mean annual precipitation of 1,172 $\mathrm{mm}$ (BPS Ngawi, 2018). Approximately $90 \%$ of the precipitation falls between November and April, and a small amount of precipitation occurs between May and October. The research design was a randomized complete block design, with four blocks as replications (Figure 1). The treatment was four plant spacing distances of $3 \mathrm{~m} \times 3 \mathrm{~m}, 6 \mathrm{~m} \times 2 \mathrm{~m}, 8 \mathrm{~m} \times 2 \mathrm{~m}$, and $10 \mathrm{~m} \times 2 \mathrm{~m}$ (Figure 2). The plot for each treatment is a square plot of $4 \times$ 50 plants. The stand density per hectare is in the range of 500-1,111 individuals $\mathrm{ha}^{-1}$, depending on their spacing (Table 1).

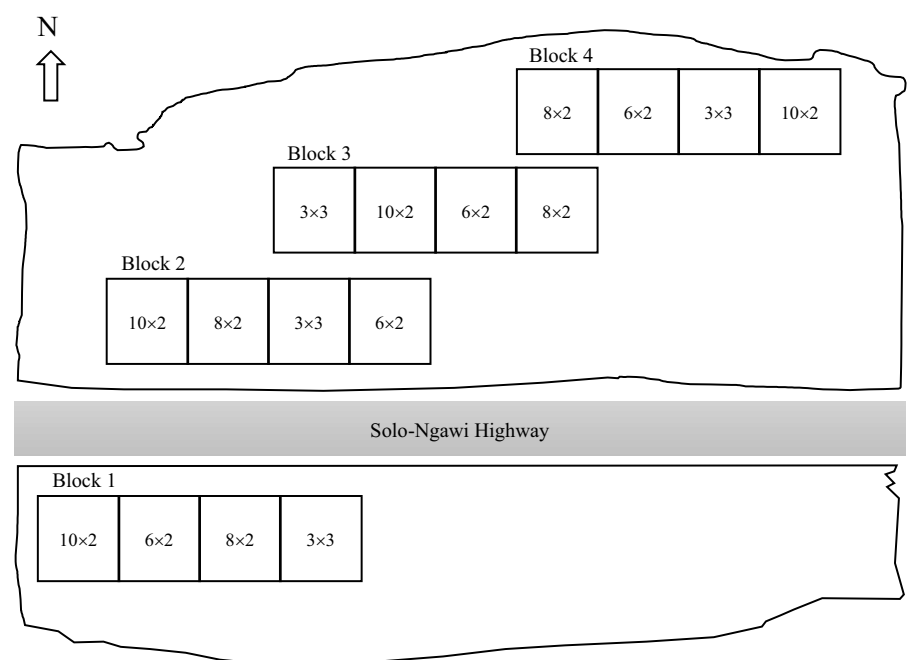

Figure 1 Layout of superior teak clones in four blocks.
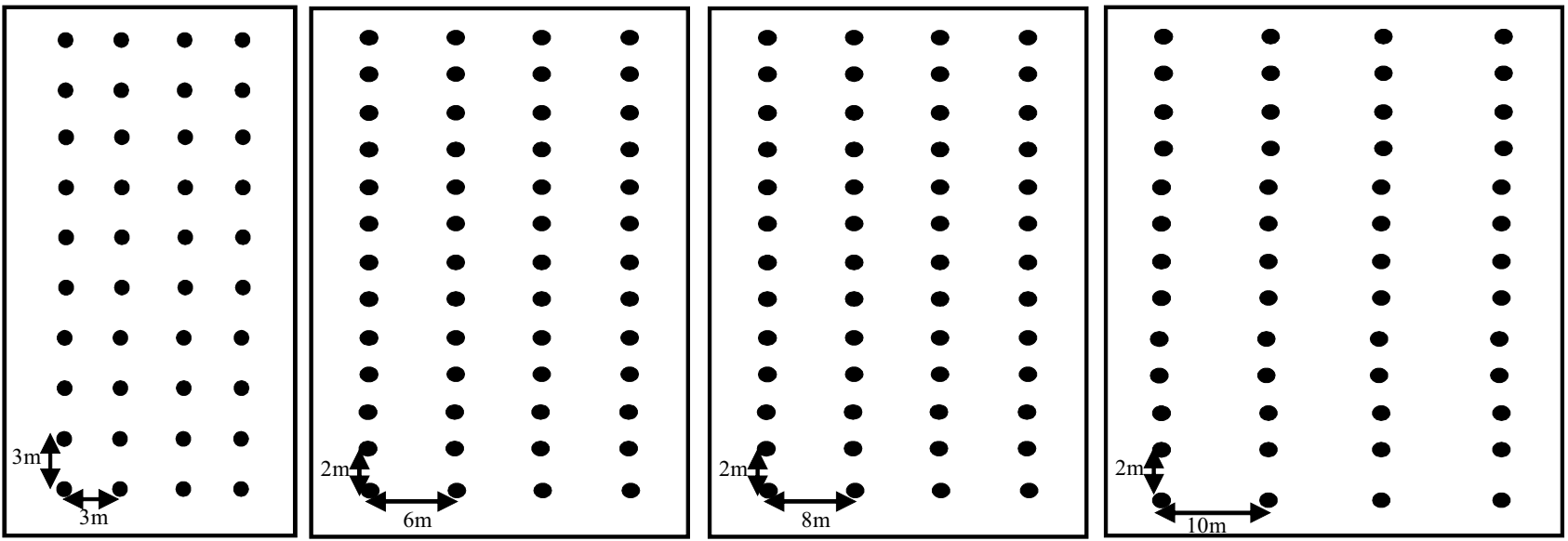

Figure 2 Various planting distances of superior teak clones. 
Data collection and analysis The collected data in our research are tree growth, stem form, volume, and competition index (CI) of clonal teak plantation. The tree growth parameters observed in this study are diameter at breast height $(\mathrm{DBH})$ and height of the tree. The stem form data include bole height, branch angle, crown area, and crown projections. The tree height and free height of the branches are measured by using a Haga meter, while the diameter of the tree is measured by using a tape diameter at breast height of $1.3 \mathrm{~m}$. The branching angle of the tree in this observation is divided into four classes, namely, class 1 $\left(0^{\circ}-22.5^{\circ}\right)$, class $2\left(22.6^{\circ}-45^{\circ}\right)$, class $3\left(45.1^{\circ}-67.5^{\circ}\right)$, and class $4\left(67.6^{\circ}-90^{\circ}\right)($ Table 2$)$.

Horizontal and vertical projection was performed by using SExI-FS software (Vincent \& Harja, 2008). To characterize the horizontal and vertical spatial of individuals in each plot, the $(\mathrm{x}, \mathrm{y})$ positions of each tree in each plot were recorded using a tape measure. Thus, the vertical projection of the individual tree crown was delineated from the radial length of the crown in the north, south, east, and west sides, in addition to crown depth of the trees. Individual crown area was visualized using a three-dimensional spatial model with SExI-FS (Vincent \& Harja, 2008).

The determination of tree growth space depends on the size of the tree canopy because it is related to the physiological space of the tree and can describe the projected area and area of the tree canopy (Pretzsch et al., 2015). The crown area is estimated on the basis of the assumption that the crown area is equivalent to the shape of a circle, which is calculated using the mean of the radius of the crown as shown in Equation [1].

$$
\mathrm{L}=\pi \mathrm{r}^{2}
$$

note: $\pi=3.14, \mathrm{r}=$ the mean of the radius of the header

The CI of each individual tree (subject tree) is calculated using the Hegyi formula (1974) as shown in Equation [2].

$$
\mathrm{CI}_{\mathrm{H}}=\sum_{j=1}^{n}\left[\frac{\left(\frac{d j}{d i}\right)}{R_{i j}}\right]
$$

note: $d i=\mathrm{DBH}$ in cm of subject tree- $i, d j=\mathrm{DBH}$ in $\mathrm{cm}$ of competitor tree- $j, R i j=$ distance in $\mathrm{m}$ between subject tree- $i$ and competing tree- $j, n=$ number of competitor trees around the subject tree- $I$.

For the average radius of the canopy, the average square (Pretzsch et al., 2015) is calculated as shown in Equation [3].

$$
C R=\sqrt{\frac{r E^{2}+r W^{2}+r S^{2}+r N^{2}}{4}}
$$

note: $\mathrm{CR}=$ crown radius, $\mathrm{rE}=$ crown radius in the east direction, $\mathrm{rW}=$ crown radius in the west direction, $\mathrm{rS}=$ crown

Table 1 Stand density (number of trees per hectare)

\begin{tabular}{cc}
\hline Spacing & Stand density $\left(\right.$ trees ha $\left.{ }^{-1}\right)$ \\
\hline $3 \mathrm{~m} \times 3 \mathrm{~m}$ & 1,111 \\
$6 \mathrm{~m} \times 2 \mathrm{~m}$ & 833 \\
$8 \mathrm{~m} \times 2 \mathrm{~m}$ & 625 \\
$10 \mathrm{~m} \times 2 \mathrm{~m}$ & 500 \\
\hline
\end{tabular}

radius in the south direction, $\mathrm{rN}=$ crown radius in the north direction

The magnitude of the CI is the accumulation of the total CI between trees that intersect with the subject tree. The subject tree is the tree that is the object of research in measuring the CI. This distance is expected to provide a representative result to measure the $\mathrm{CI}$ depending on distance. If the distance between competitors and the subject tree is becoming shorter, then the CI value will be higher, and the CI value will be lower if the distance between competitors and the subject tree increases.

Volume $\left(\mathrm{m}^{3}\right)$ of individual trees was calculated using the following formula (Perez \& Kanninen, 2003) as shown in Equation [4].

$$
\mathrm{V}=(-0,0884+0,0297 * \mathrm{DBH})^{2}
$$

note: $\mathrm{V}=$ volume $\left(\mathrm{m}^{3} \mathrm{ha}^{-1}\right), \mathrm{DBH}=$ diameter at breast height (cm).

Data were analyzed using one-way ANOVA to determine the effect of planting distance on diameter growth (DBH), height, bole height, branch angle, crown area, crown projections, $\mathrm{CI}$, and volume. Duncan's multiple regression test was used for multiple comparisons among treatment means. All the analyses were performed with SPSS statistical software version 18.0 (SPSS, Inc., Chicago, IL, USA).

\section{Results and Discussion}

Space planting significantly affected the development of DBH $(\mathrm{F}=52.12)$, branch angle $(\mathrm{F}=7.94)$, crown area $(\mathrm{F}=$ $303.15)$, and $\mathrm{CI}(\mathrm{F}=57.514)$ on teak clones seven years after planting (Table 3 and Table 4). However, spacing did not affect the height growth of the teak clones seven years after planting $(\mathrm{F}=0.48)$ (Table 3$)$. The $10 \mathrm{~m} \times 2 \mathrm{~m}$ spacing produced the highest $\mathrm{DBH}(23.03 \mathrm{~cm})$, branch angle $\left(61.95^{\circ}\right)$, and crown area $\left(31.21 \mathrm{~m}^{2}\right)$ among all treatments (Figure $3 \mathrm{~A}$, Figure $4 \mathrm{~A}$, and Figure $5 \mathrm{~A}$ ). The $3 \mathrm{~m} \times 3 \mathrm{~m}$ spacing obtained the lowest $\mathrm{DBH}(17.85 \mathrm{~cm})$, branch angle $\left(50.96^{\circ}\right)$, and crown area $\left(13.84 \mathrm{~m}^{2}\right)$ among all treatments (Figure 3A, Figure 4A, and Figure 5A). Our results indicate that the spacing would increase the number of individuals with a large $\mathrm{DBH}$, where the number of individuals of the class $\mathrm{DBH}>25$ $\mathrm{cm}$ at $10 \mathrm{~m} \times 2 \mathrm{~m}$ spacing was the highest among all spacing treatments (Figure 6). The $10 \mathrm{~m} \times 2 \mathrm{~m}$ spacing would increase the growth of teak clones by $22.5 \%$ compared with $3 \mathrm{~m} \times 3 \mathrm{~m}$ spacing, with a MAI diameter at $10 \mathrm{~m} \times 2 \mathrm{~m}$ and $3 \mathrm{~m} \times 3 \mathrm{~m}$ of $3.3 \mathrm{~cm}$ year $^{-1}$ and $2.5 \mathrm{~cm}$ year $^{-1}$, respectively. However, DBH MAI of $3 \mathrm{~m} \times 3 \mathrm{~m}$ spacing in our study was $72 \%$ higher than the growth of teak in Tanzania (Zahabu et al., 2015). Furthermore, the MAI of teak DBH in Nicaragua at $1 \mathrm{~m} \times 1 \mathrm{~m}$ spacing was $0.8 \mathrm{~cm}$ year ${ }^{-1}$ indicating that lower growth than the $3 \mathrm{~m} \times 3 \mathrm{~m}$ spacing in our study and Tanzania (Haninec et

Table 2 Division of classes of branch angle $\left({ }^{\circ}\right)$

\begin{tabular}{cc}
\hline Branch angle $\left(^{\circ}\right)$ & Class \\
\hline $0-22.5$ & 1 \\
$22.6-45$ & 2 \\
$45.1-67.5$ & 3 \\
$67.6-90$ & 4 \\
\hline
\end{tabular}


Table 3 Effect spacing on DBH, height, branching angle, and crown area at seven years after planting

\begin{tabular}{lllllllcll}
\hline $\begin{array}{l}\text { Source of } \\
\text { variation }\end{array}$ & df & \multicolumn{2}{l}{ DBH $(\mathrm{cm})$} & \multicolumn{2}{l}{ Height $(\mathrm{m})$} & \multicolumn{2}{l}{ Branching angle $\left(^{\circ}\right)$} & \multicolumn{2}{l}{ Crown area $\left(\mathrm{m}^{2}\right)$} \\
\hline & & MSE & F value & MSE & F value & MSE & F value & MSE & F value \\
Block & 3 & 4.87 & 13.64 & 1.36 & 4.31 & 44.93 & 3.59 & 2158.118 & 45.564 \\
Spacing & 3 & 18.60 & $52.12^{* *}$ & 0.15 & $0.48 \mathrm{~ns}$ & 99.20 & $7.94^{*}$ & 14358.451 & $303.150^{* *}$ \\
\hline
\end{tabular}

Note: $\mathrm{df}=$ degrees of freedom; MSE $=$ mean squared error; $*$ significant at $p$-value $<0.05 ; * *$ significant at $p$-value $<0.01 ; \mathrm{ns}=$ nonsignificant at $\mathrm{t}_{\alpha 00}$

Table 4 Effect spacing on bole height, volume, and CI at seven years after planting

\begin{tabular}{lccccccc}
\hline \multirow{2}{*}{ Source of variation } & df & \multicolumn{3}{c}{ Bole Height $(\mathrm{m})$} & \multicolumn{2}{c}{ Volume $\left(\mathrm{m}^{3} \mathrm{ha}^{-1}\right)$} & \multicolumn{2}{c}{ CI } \\
\cline { 2 - 8 } & & MSE & F value & MSE & F value & MSE & F value \\
\hline Block & 3 & 2.95 & 4.86 & 242351.069 & 45.361 & 0.575 & 14.539 \\
Spacing & 3 & 2.35 & $3.86^{*}$ & 224673.828 & $42.052^{* *}$ & 2.275 & $57.514^{* *}$ \\
\hline
\end{tabular}

Note: $\mathrm{df}=$ degrees of freedom; MSE $=$ mean squared error; * significant at $p$-value $<0.05$; ** significant at $p$-value $<0.01 ;$ ns $=$ non significant at $\mathrm{t}_{\mathrm{\alpha} 0.05}$
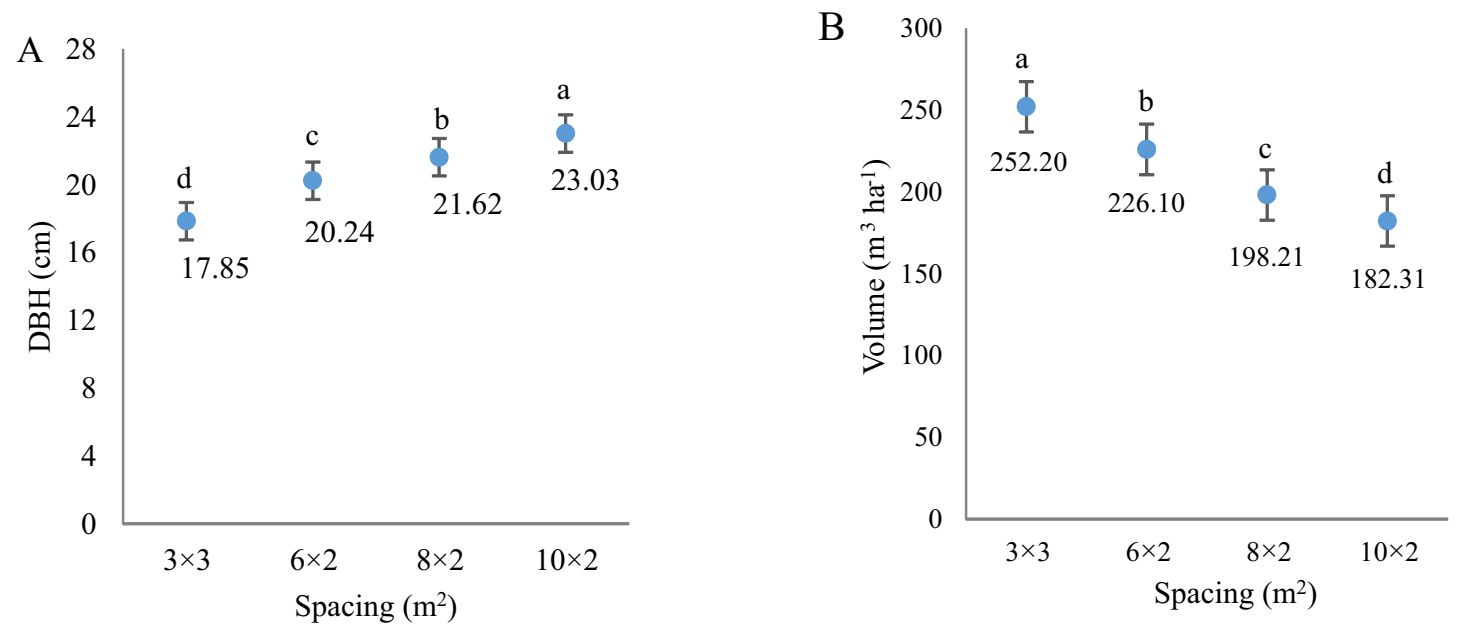

Figure 3 Means and 95\% confidence intervals for diameter at breast height/DBH (A) and volume (B) for each spacing treatment.

Different letters indicate significant differences among spacing at $\mathrm{t}_{\alpha 0.05}$.
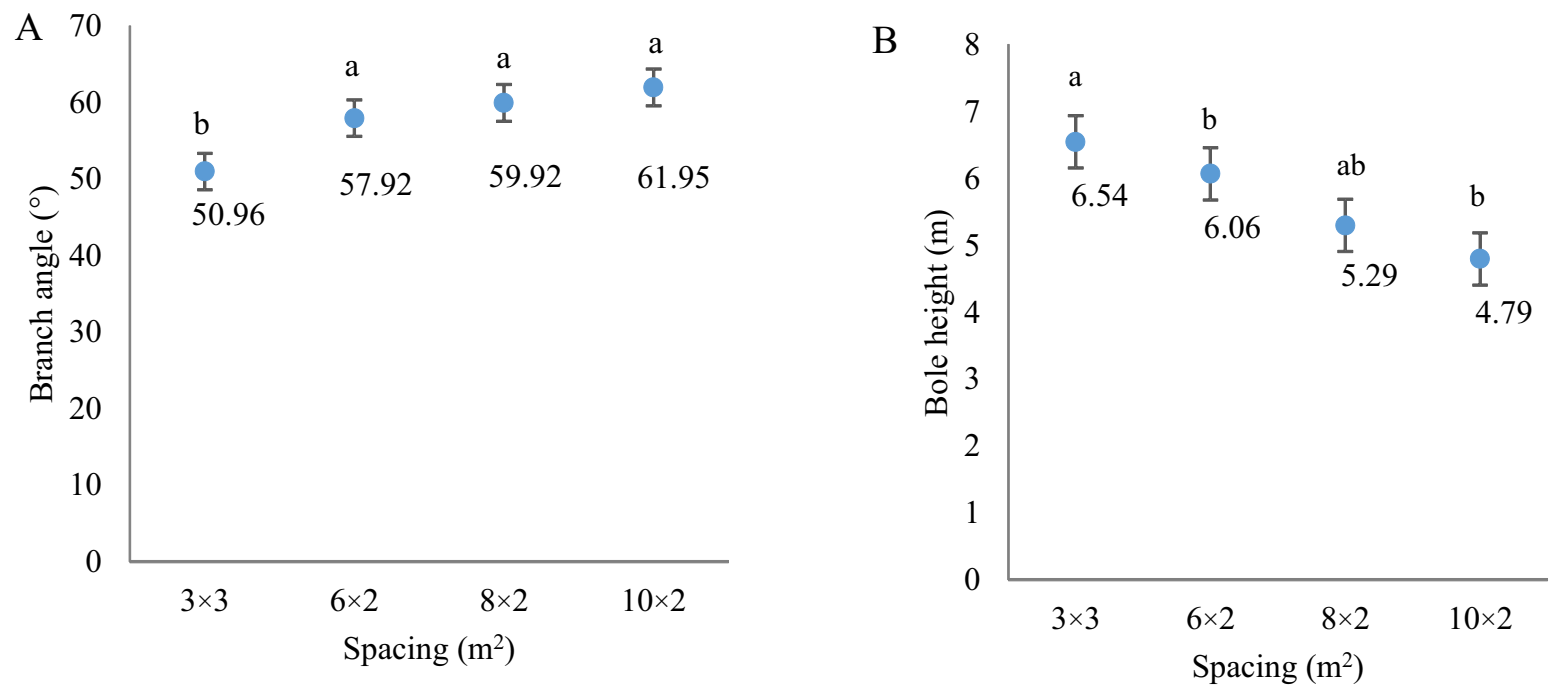

Figure 4 Means and 95\% confidence intervals for branch angle (A) and bole height (B) for each spacing treatment. Different letters indicate significant differences among spacing at $\mathrm{t}_{\alpha 0.05}$. 

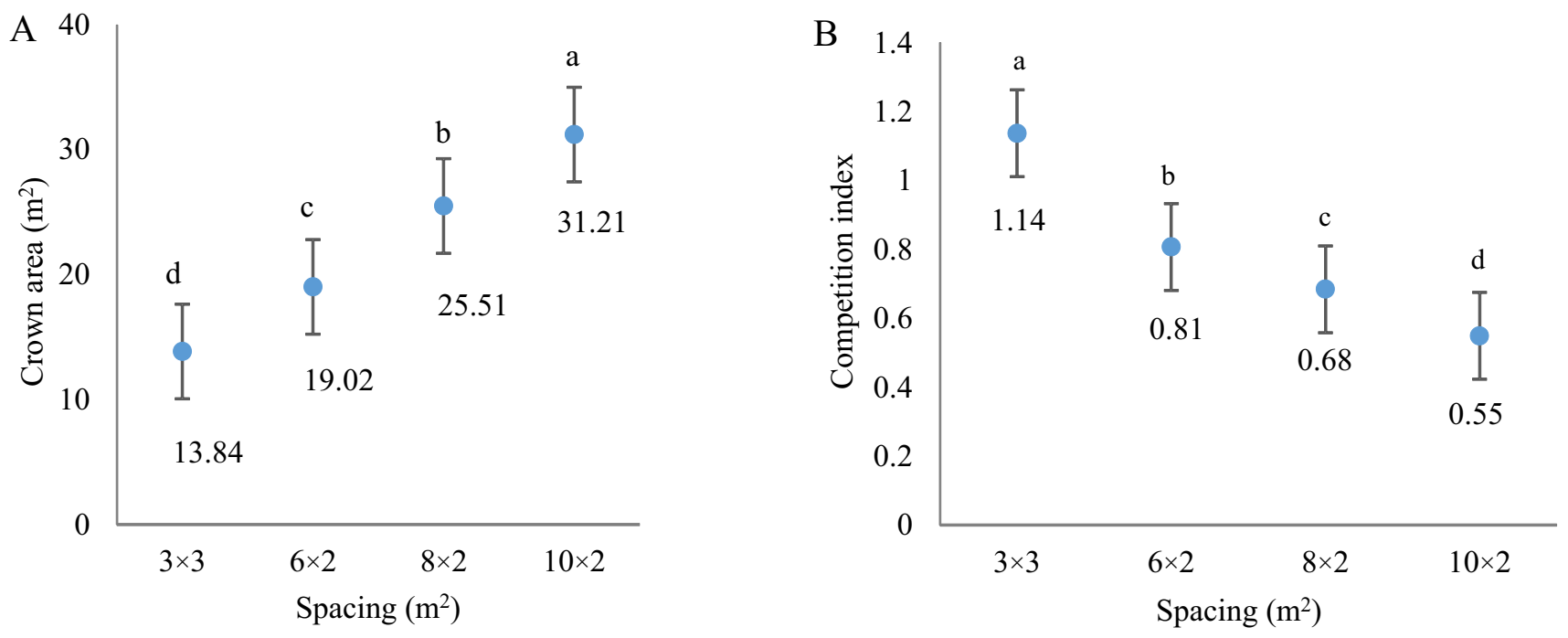

Figure 5 Means and 95\% confidence intervals for crown area (A) and CI (B) for each spacing treatment. Different letters indicate significant differences among spacing at $\mathrm{t}_{\mathrm{\alpha} 0.05}$.

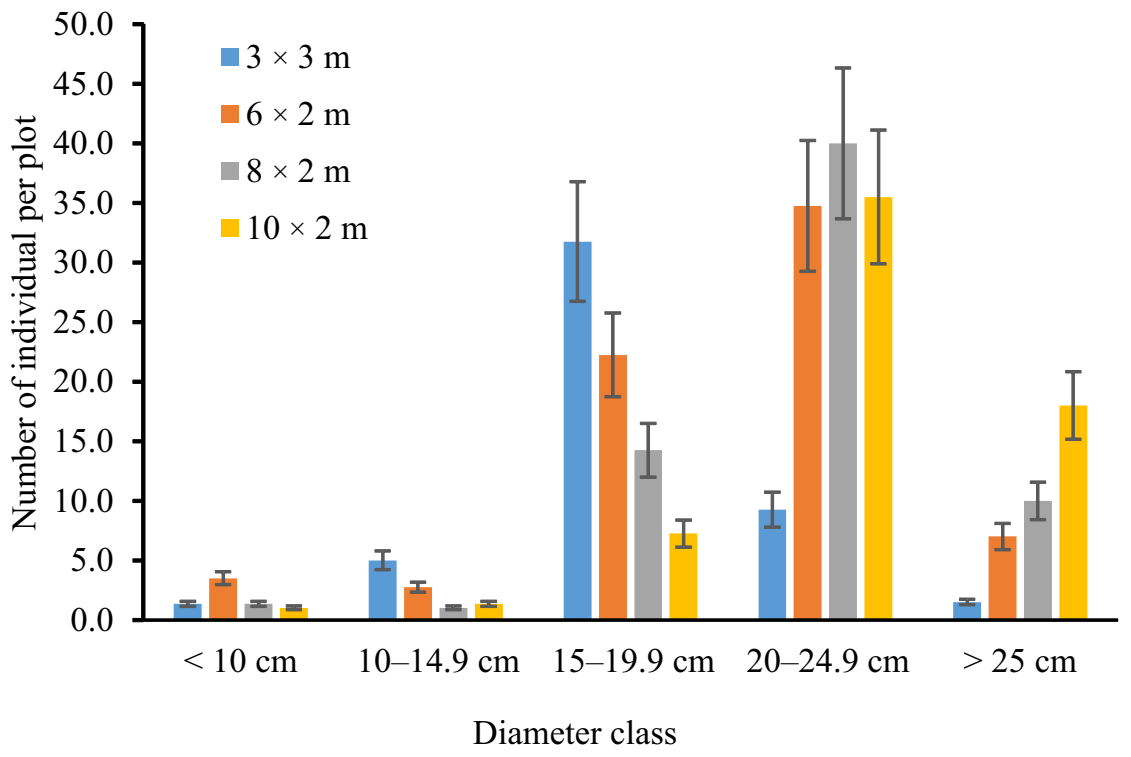

Figure 6 Graph of diameter class of superior teak clones at four plant spacing distances.

al, 2016). On the other hand, the physical and chemical soil properties was an important factor affecting the teak growth (Tanaka et al., 1998; Zhou et al., 2017) but it was not main factor in our research because all of the treatments were in same soil fertility condition. This finding suggests that the selected teak clone with wider spacing would increase diameter of the teak plantation. Perez and Kaninen (2005) observed a significantly rapid decrease in the MAI of teak as planting spacing decreases.

Moreover, spacing affected the growth of bole height $(\mathrm{F}=3.86)$ and volume per hectare $(\mathrm{F}=42.052)$ (Table 4$)$. The $3 \mathrm{~m} \times 3 \mathrm{~m}$ spacing produced the best growth of bole height $(6.54 \mathrm{~m})$ (Figure 4B) and volume $\left(252.2 \mathrm{~m}^{3} \mathrm{ha}^{-1}\right)$ (Figure $3 \mathrm{~B}$ ) among all treatments. The $10 \mathrm{~m} \times 2 \mathrm{~m}$ spacing produced the lowest bole height (4.79 m) (Figure 4B) and volume (182.31 $\mathrm{m}^{3} \mathrm{ha}^{-1}$ ) (Figure 3B). The CI was significantly different among spacing $(\mathrm{F}=57.514)$ (Table 4$)$, with the highest $\mathrm{CI}$ of 1.14 and the lowest $\mathrm{CI}$ of 0.55 for the $3 \mathrm{~m} \times 3 \mathrm{~m}$ and $10 \mathrm{~m} \times 2$ $\mathrm{m}$ spacing, respectively (Figure $5 \mathrm{~B}$ ). The increase in $\mathrm{DBH}$ from teak clones was strongly influenced by spacing as a function of plant growth space and density of individuals (Nahuel et al., 2019). The DBH of the $3 \mathrm{~m} \times 3 \mathrm{~m}$ spacing was $22 \%$ lower than that of the $10 \mathrm{~m} \times 2 \mathrm{~m}$ spacing because the stand density of $3 \mathrm{~m} \times 3 \mathrm{~m}$ was $50 \%$ greater than that of the 10 $\mathrm{m} \times 2 \mathrm{~m}$ spacing (Table 1 ). The reduction in DBH was due to teak being an intolerant species that requires more open space for growth (Budiadi et al., 2017; Zahabu et al., 2015; Ola-Adams, 1990). However, an increasing number of 
individuals would increase the CI of teak clones by $51.7 \%$ (Figure 5B), reduce the development of canopy and roots (Zahabu et al., 2015), and suppress teak growth (Pachas et al., 2019; Ugalde, 2013). Moreover, the $10 \mathrm{~m} \times 2 \mathrm{~m}$ spacing (20 $\mathrm{m}^{2}$ ) increased the development of the canopy area by $55.6 \%$, which is greater than that of $3 \mathrm{~m} \times 3 \mathrm{~m}$ spacing seven years after planting (Figure 7). This condition might be caused by increasing intraspecific competition, which suppresses the growth of higher-density stands (Woodruff et al., 2002). This finding showed that spacing $3 \mathrm{~m} \times 3 \mathrm{~m}$ should be thinned earlier than others spacing due to the highest CI value. On the other hand, the fast growth of teak clones needs appropriate space along rotation maintaining their growth through thinning. For instance, the $50 \%$ intensity of thinning at 5 years after planting increased diameter growth than unthinned stand (Budiadi et al., 2017), because thinning would reduce density and increase spacing of the residual stand (Budiadi et al., 2017). This finding also suggests that increasing the spacing will increase the width of the plant canopy so that it is likely to increase photosynthesis and the capture of sunlight used in photosynthetic activity, thereby enhancing the tree growth (Meng et al., 2007).

In contrast, spacing has no significant effect on the height growth of teak ( $p$-value) (Table 3$)$, with the best of spacing for height growth being $8 \mathrm{~m} \times 2 \mathrm{~m}$ (Figure 8 ). This result may have occurred probably because height growth is affected by site quality (Malimbwi et al., 1992; Cardoso et al., 2013; Medeiros et al., 2018), thereby indicating that the height growth of teak is not affected by stand density (Cardoso et al., 2013; Medeiros et al., 2018), but the height growth is sensitive to differences in site quality. Ola-Adams (1990) examined the effect of spacing on the growth and yield of Tectona grandis and Terminalia superba. Spacing has no significant effect on the mean total height of teak, but $T$. superba showed significant differences in mean total height with increasing spacing. This result suggests that the

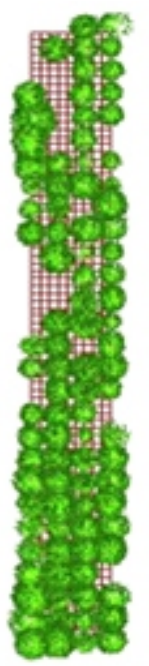

(a)

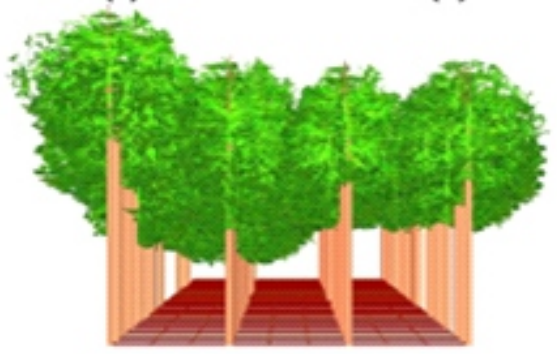

(a)

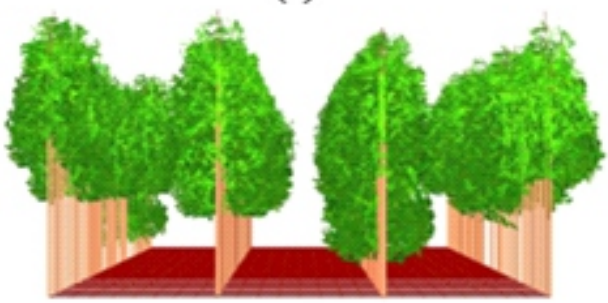

(c)

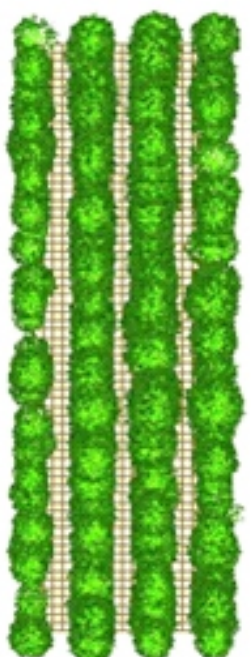

(b)

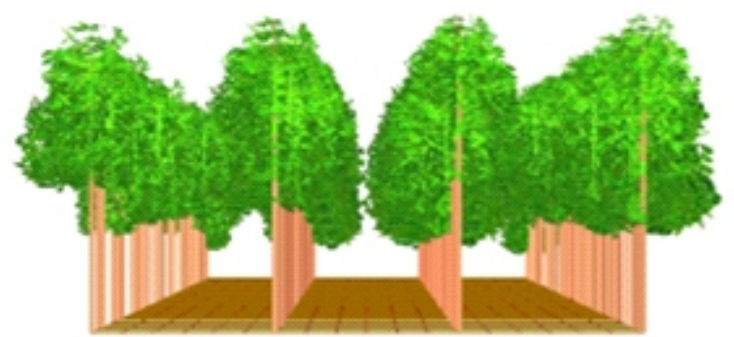

(b)

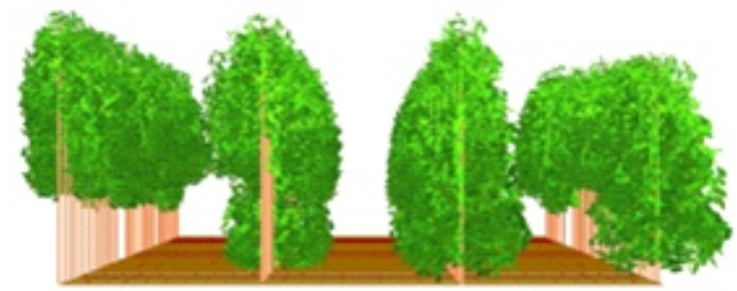

(d)

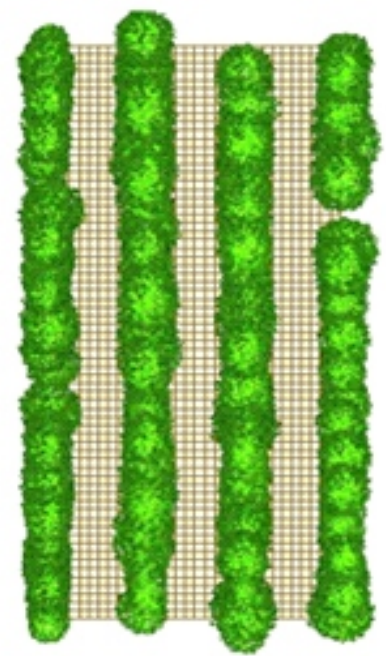

(d) (c)

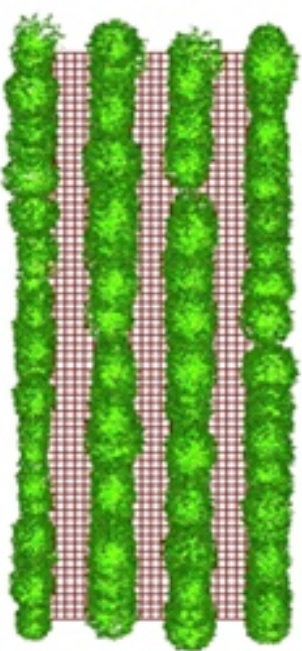

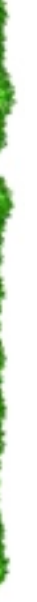




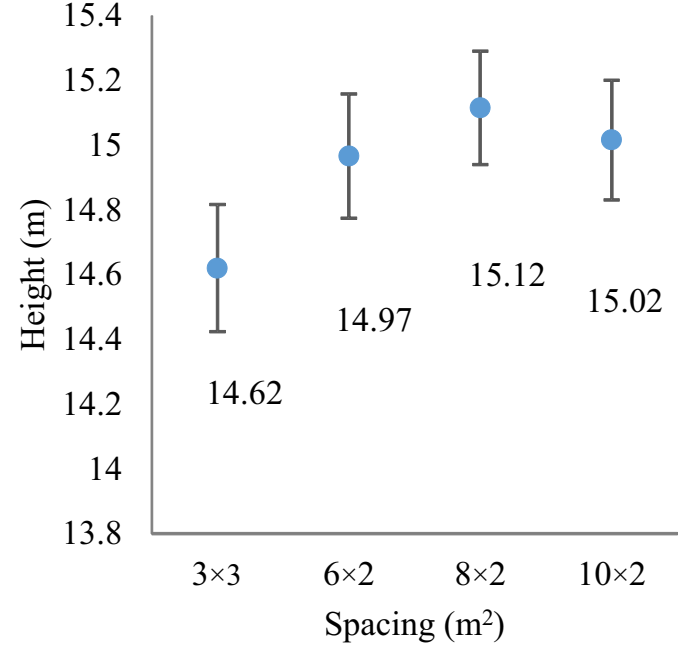

Figure 8 Means and 95\% confidence intervals for height for each spacing treatment.

different height growth is affected not by stand density but by site quality and genetics.

Implications of spacing for teak wood products In production forests for saw timber purposes, forest plantations play an important role in obtaining desired wood characteristics and optimizing growth (Pfister et al., 2007) because one of the factors that affect the price of teak wood is log size. The price of small log (AI grade, diameter: 16-19 $\mathrm{cm}$ ), medium log (AII grade, diameter: 22-28 cm), AIII grade (diameter: $30-39 \mathrm{~cm}$ ), and AIV grade (diameter: 40-49 $\mathrm{cm}$ ) differ according to size.

Increasing the spacing would improve the diameter growth, but it would decrease the bole height and increase the branch angle. Increasing the spacing $(10 \mathrm{~m} \times 2 \mathrm{~m})$ would reduce the bole height by around $36.5 \%$ compared with the 3 $\mathrm{m} \times 3 \mathrm{~m}$ spacing. Bole height is important for teak plants because it is related to wood quality and is the most important characteristic in determining the value of teak wood (Goh, 2016). A higher bole height will increase the yield of teak for its use for the construction of houses, ships, furniture, panels, joinery, and plywood, among others (Sreekanth et al., 2012). Furthermore, spacing will increase the angle of teak branching. The longest plant spacing $(10 \mathrm{~m} \times 2 \mathrm{~m})$ produced a larger branching angle than other spacing distances. A large branching angle may probably cause greater wood defects, which will greatly reduce the quality of teak wood. In relation this matter, teak planting with a wide spacing must be followed by intensified maintenance in the form of pruning, leaving one-third of the height (Budiadi et al., 2017). Pruning maintenance will eventually produce teak plants with good DBH, total height, bole height, and optimal branching angles because the pruning action does not have a direct effect on teak growth but increases the quality of the teak wood and yields in wood processing.

\section{Conclusion}

Plant spacing in teak clones has an important role in ensuring high productivity and producing good-quality teak wood in early teak clone growth. Increasing space planting of teak, i.e. $10 \mathrm{~m} \times 2 \mathrm{~m}$, increases the $\mathrm{DBH}$ due to the development of the canopy area and reduces the Competition Index (CI), thereby producing a higher diameter class and economic value. However, increasing spacing shows in a lower bole height, which affects the wood quality. Thus, forest maintenance, i.e. pruning, should be more intensive to produce high-quality of clonal teak wood. Meanwhile, the narrow spacing, i.e. $3 \mathrm{~m} \times 3 \mathrm{~m}$, would reduce the $\mathrm{DBH}$ growth due to increasing competition index among individuals. The high number of individuals in the same area will increase the CI of teak clones by $72.5 \%$ and decrease the area of the teak canopy area. Thus, thinning as forest activity should be done earlier to maintain the DBH growth of residual trees. For this reason, a combination of plant spacing and plant maintenance in the form of pruning and thinning can ensure good teak clone growth and quality.

\section{References}

Budiadi, Widiyatno, \& Ishii, H. (2017). Response of a clonal teak plantation to thinning and pruning in Java, Indonesia. Journal of Tropical Forest Science, 29, 44-53. Retrieved from http://www.jstor.org/stable/44028274

[BPS] Badan Pusat Statistik Ngawi. (2018). Rata-rata curah hujan tiap bulan menurut lokasi penakar di Kabupaten Ngawi 2016-2017. Retrieved from https://ngawikab. bps.go.id

Cardoso, D. J., Lacerda, A. E., Rosot M. A., Garrastazú, M. C., \& Lima R. T. (2013). Influence of spacing regimes on the development of loblolly pine (Pinus taeda) in southern Brazil. Forest Ecology Management, 310, 761-769. https://doi.org/10.1016/j.foreco.2013.09.021

Contreras, M. A., Affleck, D., \& Chung, W. (2011). Evaluating tree competition indices as predictors of basal area increment in western Montana forests. Forest Ecology Management, 262, 1939-1949. https://doi.org/ 10.1016/j.foreco.2011.08.031

[FAO] Food and Agriculture Organization. (2013). Natural teak forests decline, while planted teak forests increase. Food and Agricultural Organization of United Nations.

Goh, D. K. S. (2016, February 22-26). Rationale for clonal teak plantations [Paper presentation]. Asia-Pacific Forestry Week 2016, Pampanga, Philippines. Retrieved from http://www.fao.org/fileadmin/user_upload/ rap/Asia-Pacific_Forestry_Week/doc/Stream_1/ ST1_25Feb_Goh_Teak.pdf

Haninec, P., Petr, M., Martin, S., Hana, H., Martin, S., Lubos, U., Milan, R., Jindr I.P., Josef, C., Katerina N., \& Radek, S. (2016). Assessment of teak production characteristics using $1 \mathrm{~m}$ spacing in a plantation in Nicaragua. Bois Et Forets Des Tropiques, 300, 37-47. https://doi.org/ 10.19182/bft2016.330.a31317

Harrington, T. B., Harrington, C. A., \& DeBell, D. S. (2009). Effects of planting spacing and site quality on 25-year growth and mortality relationships of Douglas-fir (Pseudotsuga menziesii var. menziesii). Forest Ecology 
and Management, 258, 12-25. https://doi.org/10.1016/ j.foreco.2009.03.039

Hegyi, F. (1974). A simulation model for managing jack-pine stands. In Fries, J. (Ed.), Growth models for tree and stand simulation. Stockholm: Royal College of Forestry.

Iddi, S., Chamshama S. A., \& Malimbwi, R. E. (1996). Planting spacing in forest plantation: A review, record 63, Faculty of Forestry. Morogoro, Tanzania: Sokoine University of Agriculture.

Kollert, W., \& Cherubini, L., (2012). Teak resources and market assessment 2010. FAO Planted Forests and Trees Working Paper FP/47/E. Rome. Retrieved form http://www.fao.org/3/a-an537e.pdf

Kollert, W., \& Kleine, M. (Eds.) (2017). The global teak study: Analysis, evaluation and potential of teak resources. Vienna: IUFRO World Series Volume 36. Retrieved from https://www.iufro.org/uploads/ media/ws36.pdf

Ling, L. T., Yap, S., Radhakrishnan, A. K., Subramaniam,T., Cheng, H. M., \& Palanisamy, U. D. (2009). Standardized Mangifera indica extract is an ideal antioxidant. Food Chemistry, 113, 1154-1159. https://doi.org/10.1016/ j.foodchem.2008.09.004

Maleki, K., Kiviste, A., \& Korjus, H. (2015). Analysis of individual tree competition effect on diameter growth of silver birch in estonia. Forest Systems, 24, e023. https://doi.org/10.5424/fs/2015242-05742

Malimbwi, A., Persson, S., Iddi, S., Chamshama, S. A. O., \& Mwihomeke, S. T. (1992). Effects of spacing on yield and some wood properties of Pinus patula at Rongai, Northern Tanzania. Forest Ecology and Management, 53, 297-306. https://doi.org/10.1016/0378-1127(92)90048-e

Medeiros, R. A., Paiva, H. N., \& D'Ávila, L. (2018). Growth and yield of teak stands at different spacing. Pesquisa Agropecuaria Brasileira Brasília, 53, 1109-1118. https://doi.org/10.1590/s0100-204x2018001000004

Meng, S. X., Leiffers, V. J., \& Huang, S. (2007). Modelling crown volume of lodgepole pine based upon uniform stress theory. Forest Ecology and Management, 251, 174-181. https://doi.org/10.1016/j.foreco.2007.06.008

[MoF] Ministry of Forestry. (2012). Statistik Kehutanan Indonesia 2011. Jakarta: Ministry of Forestry Indonesia.

Nahuel, A. Pachas, A. N. A., Sakanphet, S., Soukkhy, O., Lao, M., Savathvong, S., ..., \& Dieters, M.J. (2019). Initial spacing of teak (Tectona grandis) in northern Lao PDR: Impacts on the growth of teak and companion crops. Forest Ecology and Management, 435, 77-88. https://doi.org/10.1016/j.foreco.2018.12.031

Na'iem, M. (2000). Early performance of clonal tests of teak. In E. B. Hardiyanto (Ed.), Third regional seminar on teak.
Potential and opportunities in marketing and trade of plantation teak: Challenge for the new millenium (pp 217-275). Faculty of Forestry Universitas Gadjah Mada.

Na'iem, M. (2012). Peningkatan produktivitas hutan berbasis silvikultur intensif (SILIN): Strategi efisiensi penggunaan kawasan hutan. In A. Nugraha (Ed.), Darurat hutan Indonesia, mewujudkan arsitektur baru kehutanan Indonesia (pp.162-183). Banten: Wana Aksara.

Ola-Adams, B. A. (1990). Influence of spacing on growth and yield of Tectona grandis L.f. and Terminalia superba Engl. \& Diels (Afara). Journal of Tropical Forest Science, 2, 180-186. Retrieved from https://www.jstor.org/stable/43594330

Pachas, A. N. A., Somphanh, S., Outhai, S., Maichor, L., Sianouvong, S., Jonathan, C., ..., \& Mark, J. (2019). Initial spacing of teak (Tectona grandis) in Northern Lao PDR: Impacts on the growth of teak and companion crops. Forest Ecology and Management, 435, 77-88. https://doi.org/10.1016/j.foreco.2018.12.031

Palanisamy, K., Gireesan, K., Nagarajan, V., \& Hegde, M. (2009). Selection and clonal multiplication of superior trees of teak (Tectona grandis) and preliminary evaluation of clones. Journal of Tropical Forest Science, 21, 168-174. Retrieved from http://www.jstor.org/ stable/23616646

Perez, D., \& Kanninen, M. (2003). Provisional equations for estimating total and merchantable volume of Tectona grandis trees in Costa Rica. Forests, Trees and Livelihoods, 13, 345-359. https://doi.org/10.1080/ 14728028.2003.9752470

Perez, D., \& Kanninen, M. (2005). Stand growth scenarios for Tectona grandis plantations in Costa Rica. Forest Ecology and Management, 210, 425-441. https://doi.org/ $10.14214 /$ df. 1

Perhutani. (2014). Statistik Perum Perhutani 2009- 2013. Jakarta: Perum Perhutani.

Pfister, O., Wallentin, C., Nilsson, U., \& Eko, P. M. (2007). Effects of wide spacing and thinning strategies on wood quality in Norway spruce (Picea abies) stands in Southern Sweden. Scandinavian Journal of Forest Research, 22, 333-343. https://doi.org/10.1080/0282758 0701504951

Pretzsch, H., Biber, P., Uhl, E., Dahlhausen, J., Rötzer, T., Caldentey, J., Koike, T., Con T.V., Chavanne, A., Seifert T., Toit, B.D., Farnden, C., \& Pauleit. S. (2015). Crown size and growing space requirement of common tree species inurban centers, parks, and forests. Urban Forestry and Urban Greening, 14, 466-479. https://doi.org/10.1016/j.ufug.2015.04.006

Sreekanth, P. M., Balasundaran, M., Nazeem, P. A., \& Suma, 
T. B. (2012). Genetic diversity of nine natural Tectona grandis L.f. populations of the Western Ghats in Southern India. Conservation Genetics, 13, 1409-1419. https://doi.org/10.1007/s10592-012-0383-5

Tanaka, N., Hamazaki, T., \& Vacharangkura, T. (1998). Distribution, growth and site requirements of teak. $J A R Q, 32,65-77$.

Ugalde, L. A. (2013). Teak: New trends in silviculture: commercialization and wood production. Cartago: International Forestry and Agroforestry.

Vincent, G., \& Harja, D. (2008). Exploring ecological significance of tree crown plasticity through three dimensional modeling. Annals of Botany, 1-12. https://doi.org/10.1093/aob/mcm189

Wehr, J. B., Blamey, F. P., Smith, T. E., \& Menzies, N. W. (2016). Growth and physiological responses of teak (Tectona grandis Linn. f.) clones to $\mathrm{Ca}, \mathrm{H}$ and $\mathrm{Al}$ stresses in solution and acid soils. New Forests, 48, 137-152. https://doi.org/10.1007/s11056-016-9560-6
Woodruff, D., Barbara, J. B., Gary, A. R., \& William, S. (2002). Effects of stand density on the growth of young Douglas-fir trees. Canadian Journal of Forest Research, 32,420-427.https://doi.org/10.1139/x01-213

Zahabu, E., Tumaini, R., Shabani, A., Omari, C., Said, I., \& Rogers, E. (2015). Effect of spacing regimes on growth, yield, and wood properties of Tectona grandis at Longuza Forest Plantation, Tanzania. International Journal of Forestry Research, 1-6. https://doi.org/10.1155/ 2015/469760

Zanin, D. K. (2005). Feasibility of teak production for small holders in Eastern Panama [thesis]. Michigan: Forestry Michigan Technological University. Retrieved from https://www.mtu.edu/peacecorps/programs/forestry/pdfs /daniella-zanin-thesis-final.pdf

Zhou, Z., Liu, S., Liang, K., Ma, H., \& Huang, G. (2017). Growth and mineral nutrient analysis of teak (Tectona grandis) grown on acidic soils in South China. Journal of Forestry Research, 28, 503-511. https://doi.org/10.1007/ s11676-016-0324-0 